\title{
Corporate social responsibility: reviewed, rated, revised
}

Farrington, Tom

Curran, Ross

Gori, Keith

O'Gorman, Kevin

Queenan, Jane

This is the author approved version of the manuscript, ( 2017 Emerald publishing group. Publishing and permission has been granted for this version to appear in Abertay's research repository.

Emerald does not grant permission for this article to be further copied/distributed or hosted elsewhere without the express permission from Emerald Group Publishing Limited.

Available from: https://dx.doi.org/10.1108/IJCHM-05-2015-0236 


\section{Corporate Social Responsibility: Reviewed, Rated, Revised.}

Tom Farrington, Ross Curran, Keith Gori, Kevin O'Gorman, Jane Queenan

\section{Abstract}

\section{Purpose}

Critical literature review of CSR research in both general management and hospitality management literature. Discusses trends, commonalities, and inconsistencies to better understand the state of contemporary scholarship, and calls for a context-specific conceptual engagement with the phenomenon.

\section{Design/methodology/approach}

Systematic literature review, noting and critiquing a general tendency towards measurement of financial and other internal benefit impacts.

\section{Findings}

Hospitality management is well-positioned to evaluate the opportunities and challenges of CSR, yet research has uncritically adopted the instrumental emphasis on assessing processes, perceptions, and private profitability from the general management literature, without engaging on a contextually-specific and/or theoretical level.

\section{Research limitations}

CSR research is abundant and therefore difficult to summarise in one article. The primarily Anglo-American and Asian contextual bias is reflected in this review.

\section{Practical implications}

Consistently inconsistent results challenge the portability of financial impact studies. Studies are needed to re-evaluate the concept of CSR as it pertains to hospitality, and measure the effectiveness of CSR activities relative to context and resource availability.

\section{Social implications}

Further research into the scope of CSR in hospitality management, with an emphasis on recuperating social value, would lead to widespread positive social implications.

\section{Originality/value}

This critical review offers a new perspective on CSR in the hospitality literature and industry, calling for a reconsideration of the concept in context, and formulates a working definition.

\section{Key Words}

Corporate Social Responsibility, CSR, Literature Review, Impact. 


\section{Introduction}

Corporate social responsibility (CSR) has become ubiquitous in the hospitality and tourism industry and the academic literature. The industry itself is fraught with contradictions, from the simple 'carbon offsetting' of budget flights to the plea from the Maldivian government that their country will disappear with rising water levels whilst also building, in one year, at least seven additional airports to service their resort islands (Kundur, 2012). The academic literature is no better; the continually inconclusive or contradictory findings of financial impact studies (Inoue and Lee, 2011; Vlachos et al., 2009), often meaningless CSR reporting (de Grosbois, 2012), and consumer cynicism over perceived 'green-washing' activities (Parguel et al., 2011; Pope and Wæraas, 2015) indicate clearly that it is time for a reevaluation of CSR in both the hospitality literature and in management practice. CSR research must fundamentally debate the relevance and application of CSR to the sector and its relationship with external stakeholders, before trying to measure its internal benefit and financial impact. While the social sciences continue to engage in lively and productive debates about what CSR is, how it is used, and the ways in which its socio-political value might be recuperated (Blowfield, 2005; Gjølberg, 2009; Sandoval, 2015), research into hospitality management continues to accept as fit and applicable the many definitions, models, and measures found in general management scholarship. Our theoretical gap is this lack of critical engagement with conceptualisation, and our corresponding contextual gap is the industry application of CSR.

Understanding the theoretical foundations and practical impacts of CSR within the hospitality industry is of particular importance when responding to an increasingly selective and ethically-aware consumer base (Holcomb et al., 2007; Kim et al., 2015; Sen and Bhattacharya, 2001; Wang, 2014). Over the last sixty years, research into CSR in business and management has come to focus on measuring procedural efficiency, corporate profitability, and stakeholder perceptions of ostensibly related activities (Coles et al., 2013; Galbreath, 2010; Kemper et al., 2013; Wildes, 2008), despite occasional ethical interventions (Jones, 2003; Mintzberg, 1983; Moore, 2003). This is perhaps unsurprising, being aligned with concurrent economic and political developments towards neoliberalism (Harvey, 2005; Kinderman 2012; Larner, 2000; Sadler and Lloyd, 2009), and reflecting increased shareholder obligations (Hanlon 2008; Shamir, 2004). Indeed, the prioritisation of relatively mechanical measurements of professed CSR activities, over more deliberative discussions of what actually constitutes CSR, may also be understood as a reductive reaction to a multiplicity of definitions. Despite being uniquely positioned to engage with the theory and practice of CSR at a foundational level, the recent explosion of CSR studies in the hospitality literature largely follows this trend.

Before plunging into the 'corporate' element of CSR it is worth reflecting that, underpinned by the phenomenon of hospitality, the industry has always taken its social responsibility very seriously. Laws pertaining to the industry date back at least 4000 years, e.g. the Code of Hammurabi in Mesopotamia c.1800 B.C. (O’Gorman, 2010). Inscriptions make it clear that the punishment for overcharging for beer was death by drowning, and that tavern keepers were required, on pain of death, to report all felonious customers (O'Gorman, 2009). As 
Bryce et al. (2013) note, establishing caravanserai to provide hospitality for travellers is often reflected among the traditions and writings of the early Islamic World, and the social responsibility was exacting, e.g. in 719 AD:

[...] establish inns in your lands so that whenever a Muslim passes by, you will put him up for a day, and a night and take care of his animals; if he is sick, provide him with hospitality for two days and two nights; and if he has used up all of his provisions and is unable to continue, supply him with whatever he needs to reach his hometown (al-Tabarī, [838]/1989).

A similar set of principles is derived from St Benedict's Rule by Morrison and O'Gorman (2008), through which hospitality is shown to be founded upon ethical responses to those in need, and imbued in management practice. This historical attention to basing what is right and wrong in the business of hospitality upon the needs of society is of particular significance to the following critical evaluation of CSR research.

In order to review just what contemporary CSR might be for hospitality management, the paper now splits into five sections. The first section offers an overview of the development of CSR in general management, before the second describes the methodology driving our systematic review of CSR literature in hospitality management. This literature review forms the third section, engaging with the treatment of CSR in the hospitality management literature. The concluding sections discuss our key findings, offer theoretical and practical contributions, suggest avenues for further research, and acknowledge limitations.

\section{The development of CSR in general management}

Described as the 'father' of CSR by Carroll (1999), Bowen (1953) highlighted the impact of leading businesses upon the lives of citizens and asked what responsibilities this impact placed upon them. For Bowen, (1953) social responsibility was the obligation on business leaders to make decisions and pursue goals that followed actions desirable in the context of social objectives and values, an idea most famously challenged by Friedman (1970, p. 122), who claimed the social responsibility of the business is "to use its resources and engage in activities designed to increase its profits... without deception or fraud.” Tempered by a minimal adherence to legal regulations, Friedman's (1970) approach to CSR is updated by Henderson (2005), and represents the 'ethical' approach to CSR, with Bowen's (1953) approach representing the opposite 'altruistic' pole (Lantos, 2001, 2002). Somewhere between these, 'strategic' CSR is commonly seen in attempts to maintain the so-called 'triple bottom line' of financial, social/ethical, and environmental concerns, emerging as theory from Carroll's earlier work (1979; Lantos, 2001, 2002; van Marrewijk, 2003).

Lee (2008, p. 54) writes of the "progressive rationalization" of CSR research in the latter half of the twentieth century, being the increasing emphasis on establishing relationships between CSR and internal performance. Several meta-analyses of the literature attest to this reduction in scope (Lindgreen and Swaen, 2010; Orlitzky et al., 2011; Salzmann et al., 2005), despite the marked increase in the number of CSR studies since 2005 (Aguinis and Glavas, 2012), 
with further studies noting the emphasis on CSR as a strategy for gaining competitive advantage, rather than addressing social needs (Acquier et al., 2011; Laczniak and Murphy, 2012; Murphy and Schlegelmilch, 2013). Similarly, a restricted form of stakeholder theory dominates CSR research in the general management literature. While a full stakeholder theory holds that stakeholders include society and customers as well as corporate beneficiaries (Donaldson and Preston, 1995), the version in the majority of recent CSR papers is restricted to measuring the benefits of CSR for company stakeholders. Studies designed solely to measure the financial impact of CSR upon the company often silently assume the primacy of internal stakeholder concerns, thereby neglecting the wider theoretical underpinnings of the concept, and normalising the absence of the social.

Despite this concentration, CSR has been conceptualised and applied in an often disjointed, empirically inconsistent manner, with limited, often contradictory findings (Van Beurden \& Gössling, 2008; Lindgreen and Swaen, 2010; Pope and Wæraas, 2015; Rangan et al., 2015). This inconsistency stems partially from the elusiveness of an agreed, overarching definition (Carroll 1999; Dahlsrud, 2008); perhaps attributable to its complex evolutionary path, featuring influences including stakeholder, stewardship, and agency theory. Consequently, CSR perceptions vary widely within management literature, with Lindgreen and Swaen (2010, p. 1) asserting that this "probably impedes a full understanding among managers of what CSR should comprise and hinders further theoretical development of CSR".

Nevertheless, in parallel with hospitality research, the CSR discourse has made a notable shift from examining ethically underpinned, macro-level arguments, towards organisationallyfocused, performance-related analyses (Lee, 2008; Noland and Phillips, 2010).

Carroll (1991) accepts that a principal difficulty of defining CSR is delineating the 'social', which might be entirely internal; responding only to employee needs. Devinney (2009) notes that this difficulty proves too much for some who, removing the 'social' altogether, refer simply to their corporate responsibility. As Murphy and Schlegelmilch (2013) point out, this apparently minor semantic move downplays both the wider social participation of businesses, and even those internal social functions of the individual corporation. Sandoval (2015, p. 5) argues that the logic of this "instrumental reductionist approach" will find companies "drop[ping] the idea of CSR as soon as costs outweigh benefits... as soon as CSR can only be pursued at the expense of profit." Hanlon's (2008, p. 169) critique expresses precisely this problem, finding that "CSR is a commodity that can advantage corporations by allowing them to be perceived as legitimate and hence open up new markets." Situating the historical development of CSR in its political and economic context, Kinderman (2012), Sadler and Lloyd (2009), and Shamir (2004) variously assert that the primary functions of CSR are to deter the implementation of governmental policy through apparently voluntaristic selfregulatory activities, and offer pre-emptive compensation for the continued social irresponsibilities of neoliberalism. Scherer and Palazzo (2011, p. 899) find political CSR practices "fill the regulatory vacuum in global governance," noting the difficulties and dangers of balancing private and public political interests. In examining CSR as a form of private governance, Brammer et al. $(2012$, p. 4) stress the value of less business-centric perspectives of CSR, writing that 
"the literature on CSR, most of it published in management or business studies, has neglected the societal aspects of CSR by and large. Most of the literature has treated the 'social' element as a black box, as a set of external requirements which are translated into a functionalist, instrumental and business case rationale for social engagement by companies."

In branding CSR “a failing discipline”, Blowfield (2005, p. 174) similarly asserts that

"CSR has not fostered a rigorous debate about the business-society relationship; indeed by legitimising ways of thinking about these issues that are exclusive, it may even have prevented that debate from happening."

Both Sandoval (2015) and Fleming and Jones (2012) argue that CSR is incompatible with the profit-maximising principles keeping businesses alive, and can therefore only function as propaganda, concealing power structures that maintain social inequality. Although this may be hard to accept, external critiques are as crucial to the debate as they are damning of its industrial conclusions. CSR research in general management seems largely to have accepted that socially responsible activities are simply a public means to private ends. Furthermore, although CSR research is conducted globally by researchers of many nationalities, the common definitions are underpinned by Anglo-American understandings of CSR (Dawkins and Ngunjiri 2008). Responding to these limitations, Rangan et al. (2015, p. 49) note that:

"It's neither practical nor logical for all companies to engage in the same types of CSR, since CSR programs are driven by diverse factors including the industry and the societal environments in which businesses operate and the motivations of the people who staff, run, and govern each company."

Indeed, certain scholars advocate the concept be viewed as socially constructed, necessitating a bespoke tailoring process to particular social and organisational contexts (Carroll and Shabana, 2010; Dahlsrud, 2008; Rangan et al., 2015). The value of CSR research is thus likely to be heightened when contextually focussed, mandating our exploration of CSR in the hospitality management literature.

\section{Methodology}

Towards a deeper understanding of CSR within hospitality, we conducted a systematic review of CSR literature published in top-ranked hospitality and tourism journals. This process demanded the identification of existing relevant studies, assessing their suitability to the current study, and sorting results and findings to generate logically formed conclusions (Denizci and Mohammed, 2015; Denyer and Tranfield, 2009). Guiding the literature search, the 'Tourism and Hospitality Management' listing in the ABS Academic Journal Quality Guide 2010 allowed a range of variously ranked, but agreed base standard journals to be consulted through major online databases including ScienceDirect (Li, 2008), EBSCOhost (Denizci and Mohammed, 2015), Google Scholar (Zeng and Ryan, 2012), and the respective authors' host university journal databases (Wearing and McGehee, 2013). Using the ABS list 
to guide the search was conducive to ensuring a focus on academic journal articles widely regarded as the most reliable source of knowledge in a research field (Denizci and Mohammed, 2015), owing to the increasingly crowded and segmented manifestations of CSR within broader management literature (Dahlsrud, 2008). Search terms were deliberately concise, including any combinations of 'Corporate Social Responsibility' and 'CSR'. A search of titles, abstracts and keywords was performed and the results filtered to remove returns not substantially focused on CSR or not including original research, such as book reviews. Of the returned articles, emphasis was placed on including recent, currently relevant articles not superseded by subsequent findings, ensuring a contemporary compilation of related research (Denizci and Mohammed, 2015). Following Zeng and Ryan (2012), the dataset of 81 relevant articles was compiled into a master table, in chronological order, allowing the authors to revisit the most pertinent full texts to establish trends and developments within CSR hospitality literature (Denizci and Mohammed, 2015). Aiding the analysis, reference details as well as the application of CSR in the article, benefits of CSR, drawbacks of CSR, specific sector of focus, and the extent to which CSR was measured in the paper were delineated on the table. Despite applying a systematic approach, the literature search could not be entirely exhaustive, and was concluded in June 2014. Following reviewer responses a secondary collection of literature was performed in August 2015 to update the sample.

\section{CSR in Hospitality Management}

As Fig 1 shows, CSR research within hospitality management literature has increased in volume since 2004 . Our findings suggest that the hospitality management literature has simply adopted the narrow, predominantly instrumental approach from the general management literature without due consideration to the specific challenges and opportunities of the industry.

\section{[Insert Fig 1 here]}

The review revealed various definitions of CSR. The two most common are those of Carroll (1979, p. 500), that "[t]he social responsibility of business encompasses the economic, legal, ethical, and discretionary expectations that society has of organizations at a given point in time" (used by Dodds and Kuehnel, 2010; Holcomb et al., 2007; Lee et al., 2012; Lee et al., 2013), and the World Busines Council for Sustainable Development (1999, p. 3) definition (used by Alexander et al., 2014; de Grosbois 2012; Dodds and Kuehnel 2010; Tsai et al., 2010; Tsai et al., 2012) that

"CSR is described as the continuous commitment by business through behaving ethically in their trade and contribute to economic development, at the same time improving the quality of life of the workforce and their families as well as the local community and society at large"

Definitions are also employed from, for example, the World Bank (unreferenced, despite use in top tier journals), Holden (2009), and Wood (1991), used by Nicolau (2008), Whitfield et 
al. (2014), and Garay and Font (2012) respectively, leading to considerable definitional inconsistency.

While several authors have sought to present clear definitions of the concept, they have drawn on various understandings of the concept and have seen limited adoption of their understanding of CSR in subsequent research. As Wells et al. (2015, p. 399) note, "research on CSR in one organisation is unlikely to be directly applicable across similar organisations," yet some hospitality studies cite papers from the general management literature (Nyahunzvi, 2013; McWilliams and Siegel, 2000) that do not include a clear definition of CSR.

Hospitality-oriented CSR research is thus grounded on dubiously defined conceptualisations of CSR. Other studies offer multiple definitions with subtle differences, avoiding offering support for any particular view (Dodds and Kuehnel, 2010; Jones et al., 2006a). Several papers use generic sources to support their definitions, e.g. Kim et al. (2012), base their definition upon a functional but outdated, introductory textbook (Dibb et al., 2005). Other studies avoid an explicit definition, e.g. Lee and Heo (2009) offer neither support to prior definitions, nor an original contribution. Furthermore, Butler et al. (2013) raise the issue of practices that could be seen as CSR but are not labelled as such (e.g. pro-poor tourism), and those policies labelled as CSR that are simply good business practice (e.g. paying staff a living wage).

Whilst the general business and management literature has broadly divided CSR practices into either strategic or ethical approaches (e.g. Lantos, 2001, 2002; Mintzberg, 1983), our review of CSR research in hospitality management discerned six modes of enquiry. From this emerges a detailed map of the field, showing areas of saturation and neglect, the consequent analysis of which enables us to formulate a hospitality-specific working definition of CSR. Table 1 shows our (a posteriori) cross-categorisations of CSR research in the hospitality literature into these six types, being:

- Internal impact: articles which primarily attempt to test, measure or explain the extent to which adoption or adaptation of CSR practices affect company or industry competitive performance through, for example, improved financial performance, increased consumer attraction or loyalty, employee satisfaction and retention. For example Liu et al. (2014) measure the impact of CSR initiatives on customer loyalty, finding a positive relationship mediated by brand preference.

- External impact: articles which primarily attempt to test, measure or explain the extent to which adoption or adaptation of CSR practices affect social, environmental and community practices not directly connected to business performance. Nicolau (2008) shows the extent to which CSR initiatives within hospitality and tourism can have direct and indirect positive social impacts.

- Holistic impact: articles which attempt to test, measure or explain the extent to which adoption or adaptation of CSR practices affect both internal and external factors as outlined above. Jones et al. (2006a) investigate the contributions of CSR within the pub industry to the marketplace, employees, the environment, and their host communities. 
- Processual: articles primarily exploring issues involved with improving CSR implementation and effectiveness, e.g. articles exploring barriers to CSR implementation, methods of improving implementation, levels of employee and customer engagement with CSR practices etc. Alexander et al. (2014) find CSR policy effectiveness in UK drinking establishments impeded by staff disinterest and limited operational engagement.

- Reporting and definitional: articles exploring what CSR looks like in practice (the initiatives undertaken or reported) or which aim to define CSR in hospitality research. These papers might explore the activities which are reported under the banner of CSR and their communication (de Grosbois, 2012; Holcomb et al., 2007).

- Conceptual: articles critically engaging with the concept of CSR in hospitality research and theory, e.g., Henderson's (2007) scrutiny of CSR both theoretically and in practice within the context of a post-disaster tourist environment, exploring the reconciliation of conceptual tensions between philanthropic and commercial activities.

\section{[Insert Table 1]}

Table 1 shows the field dominated by internal impact papers, with a secondary focus on processes. This tendency is mirrored in many management sub-disciplines and sector study areas, e.g. marketing; logistics; supply chain management; accounting; and built environment studies (Carter and Jennings, 2004; Jones et al., 2006b; Nikolaou et al., 2013; Owen, 2005; Vaaland et al., 2008). Such research in hospitality management primarily focusses on financial impact upon the firm (Nyahunzvi, 2013) and consumer perceptions (DiPietro et al., 2013; Liu et al., 2014; Xu, 2014), with occasional studies of employee perspectives and intentions (Chan et al., 2014; Park and Levy, 2014).

Kang et al. (2010) discuss the three (somewhat predictable) outcomes of research into the relationship between CSR activities and financial performance: positive, negative, and no significant relationship. Kang et al. 's (2010, p. 80) study of hotel, casino, restaurant, and airline firms continues this trend of finding "industry idiosyncrasies in terms of CSR," yet asserts the need for "comparative studies across industries." Inoue and Lee (2011) find similarly mixed long- and short-term financial impacts of CSR upon airlines, casinos, hotels, and restaurants.

In finding a relationship between CSR and shareholder value in the restaurant industry, Kim and $\operatorname{Kim}(2014$, p. 121) point out that few studies account for "CSR-concerning activities" diminishing corporate reputation. Lee and Park (2009) find CSR scores (CSR strengths minus concerns) of airlines and hotels relate positively to financial performance, while no such significant relationship exists in the contexts of casinos and restaurants. Kim and Kim (2014, p. 128) ultimately find that although CSR "helps a firm outperform its rivals," it is "effective only if stakeholders (not only customers but also the employees, the government, and even investors) recognize and appreciate the socially responsible development effort." Despite this potential social emphasis, Kim and $\operatorname{Kim}(2014$, p. 128) stress that "[p]racticioners should consider CSR as a strategic concept that increases the value of key stakeholders." 
Siu et al. (2014) suggest favourable consumer perceptions of CSR in restaurants can "mitigate the negative effects of internal cause attribution on customer identification and ultimately contribute to post-recovery satisfaction" (p. 87). Several studies note the financial benefits of moral capital accumulated through CSR activity (Brown and Dacin, 1997; Godfrey, 2005; Godfrey et al., 2009; Luo and Bhattacharya 2006; Simon, 1995). Yet Skarmeas et al. (2014) find consumer scepticism arising when a company has not adequately researched individual consumer requirements.

Fu et al. (2014) find employee perceptions of CSR in the Chinese hotel industry have a positive effect on organisational citizenship behaviour, thereby improving customer experience and hotel performance. Benavides-Velasco et al. (2014) find total quality management facilitating CSR in Spanish hotels, so contributing to a sustainable competitive advantage. Rodríguez and Cruz (2007) find a positive relationship between CSR and profitability in the same context, with Martínez and Rodríguez del Bosque (2013) finding loyalty positively affected by consumer perceptions of CSR. In their study of the U.S. restaurant industry, Lee et al. (2013, p. 2) find that:

"The link between corporate social responsibility (CSR) and corporate financial performance (CFP) has been extensively examined in the management and financial economics literature with no conclusive results. Scholars have found a positive, a negative, a curvilinear, and even a zero effect of CSR on CFP."

Despite (or perhaps because of) these contradictions, the financial impact papers continue to appear, with calls for more nuanced investigations accounting for national and local contexts and consumer behaviours (Liu et al., 2014; Podnar and Golob, 2007). While these studies may be generally valuable to the academic community, for the most part, these studies are all that community has. As Table 1 shows, from the first articles bringing CSR from the general management literature into the hospitality field, to the recent trend towards financial impact analyses, theoretical engagement with the concept in the hospitality context has been mostly absent, and severely limited when occasionally present. The concept is typically transplanted from general to hospitality management without consideration of its applicability in a different context. This lack of fundamental discussion and definition of what a hospitalityspecific CSR is or might be may partially explain the widely varying results of studies claiming to measure the same thing in the same context, despite the unique challenges and opportunities that the industry presents.

For example, the hospitality industry is particularly sensitive to social and political unrest as well as terrorism, even where it occurs outside a tourist destination (Avraham, 2015). Furthermore, economic crises affecting tourists' point of origin have a demonstrable impact upon tourist behaviour (Song et al., 2011). Such economic shocks can be particularly difficult to plan for and recover from (Okumus et al., 2005). This is partially compounded by the seasonal nature of tourism and the associated volatility of the labour market stifling development of alternative industries, contributing to periods of high, and then low employment (Jolliffe and Farnsworth, 2003). On a societal level, the structural nature of the tourism and hospitality industry is skewed in favour of the wealthy (Butler et al., 2013), 
resulting in the perception of hospitality employment being low-paid and low-skilled. A reexamination of the CSR concept within tourism and hospitality is vital in a context so economically challenging, socially unjust, poorly resourced, and vulnerable to external shock. With few exceptions (e.g. Henderson, 2007), these industry-specific characteristics have not been addressed by the hospitality management literature.

At their most basic ethical level, social responsibilities are based on a simple distinction, made by each individual and society, between who is included and who excluded at times of need (Singer, 2005). Given that the fair treatment of strangers in need has been a guiding principle of hospitality for several thousand years (O'Gorman 2009, 2010), and the success of the contemporary hospitality industry relies upon the extension of trust to those unknown, research in this field is uniquely positioned to engage with the ethical ramifications of this distinctive relationship between business and society.

\section{Conclusion}

This critical review of CSR research identifies widespread definitional uncertainty, a considerable imbalance towards measurements of financial impacts upon the firm, and a general ignorance of specific industrial, socio-political, and cultural contextual factors. These limitations developed in the general management literature, before being replicated in the hospitality management literature. These financial studies are generally inconclusive, or inconsistent. The business-centric approach is useful insofar as it asserts the need for studies accounting for the local and national industrial nuances, but largely offers an uncritical, apolitical approach that sees the potential for gaining competitive advantage as the primary reason for undertaking CSR activities.

Profit-driven CSR research renders some activities more worthy than others, based solely on immediate cost efficiency and consumer perceptions, rather than on long-term social impacts (Spence and Thomson, 2009). Those activities considered inefficient or not sufficiently visible thus risk a lack of attention from businesses; a risk amplified when businesses becomes politically empowered (Scherer and Palazzo, 2011). This is in stark contrast to the guiding principles of CSR which, although originally produced in different socio-political contexts, remain important points of reference, investigation, and assessment for other, more critical scholarship in the social sciences. These studies assert the potential for corruption in businesses that view CSR activities as a highly visible means to entirely private ends. Researchers interested in CSR within hospitality have an opportunity to develop new, industry-specific theoretical approaches, which we argue should give greater primary consideration to social and environmental elements. Given the fragmentation of, and highly visible challenges to the global corporate system (Public Citizen, Occupy movement, antiTTIP campaigns, anti-WTO), a reassessment of the scope and direction of CSR research may never have been more necessary. 
Theoretical implications

Whilst we concur with Wells et al. (2015) that any working definition of CSR must take into account the particular business context and the priorities of stakeholders, these factors should be understood as providing the foundations for discussions of what can be achieved, rather than limiting the scope of CSR activities. The hospitality management literature must revisit the fundamental moral and ethical issues that complicate the act of profiting from hosting and provision. How can hospitality respond to socio-economic injustice? How can industry skills and resources benefit society and the environment? What are the limits of the industry's openness to strangers? Whilst research in subsectors may therefore work towards dedicated working definitions from such discussions, this should be with general consensus in mind. Although it is hoped that this paper demonstrates the usefulness of interdisciplinary research, the use of various definitions across sectors, without a view to incremental and sector-specific consensus, may lead to measurements of the social benefits of different activities under the same general moniker. We suggest that definitions of CSR in the hospitality sector should explicitly relate business to society and the environment in a manner that acknowledges the fundamental roles played by the latter (as consumers and settings) in supporting the former. This approach requires scholars and industry professionals to engage with the theoretical and practical debate surrounding the social utility of CSR, and explore the social responsibilities of their specific sector and context. Thus, for the hospitality industry, CSR is defined as: a company-wide commitment to improving the societal and environmental conditions upon which the business relies to sustain itself, motivated not by financial profit or legal obligations, but as an end-in-itself. The definition is necessarily open to refinement and customisation according to the specific opportunities of each sub-sector and organisation. A definition for the hotel industry, for instance, could be that, reflecting the continued support of those guests able to afford hotels, and the societal and environmental resources required to maintain hotel services, the hotel's social responsibility is to those without accommodation, and the wider society and environment from which these resources are garnered. Such definitions may be further tempered and delineated at an organisational level through consultations with stakeholders.

\section{Practical implications}

The managerial implications of the discussion above are that some (but by no means all) CSR activities should relate to the business and aim for long-term social impacts, e.g. restaurants offering compostable waste to community vegetable allotments, and that all stakeholders (including consumers and employees) may propose and decide upon these activities. The often vulnerable socio-economic environments of hospitality operations may be partially stabilised by long-term collaboration in CSR initiatives between otherwise competing businesses, e.g. hoteliers providing secure garden space for the aforementioned allotments. Further research is required to find innovative, practical approaches to managing competing stakeholder interests, and though an obvious selection process involves anonymous nomination and voting, this should be tailored to the resources of each business. 
In keeping with successful implementation of our conceptualisation of CSR, several industry implications arise, also demand a long-term perspective. First, the hospitality industry has an opportunity to engage more deeply with a standardised understanding of CSR, through which more comparable, measurable and genuinely holistic applications can be achieved. The formation of an international accreditation body that adopts our definition of CSR and applies it to the global hospitality industry could lead this process, and ensure consistency of its adoption across borders. This body could function as a conduit between academia and practice, helping to commission CSR research, and feed results back to industry.

Second, an accepted definition of CSR for hospitality should be integrated within education programmes for employees, thus encouraging frontline adoption of CSR practises towards increasing impacts. Even when formulated at senior management levels, successful CSR implementation relies upon support from all organisational levels (Chan et al., 2014; Park and Levy, 2014).

Third, definitional clarification of CSR can contribute to the long-term sustainability of the hospitality industry through improving its reputation as a whole. The very nature of the hospitality industry can require it to operate in sensitive, resource-constrained locations (Bohdanowicz, et al., 2011) which, coupled with increasing public environmental concern regarding its impact (Jones et al., 2016), has constrained positive enhancement of the sector's reputation. A uniform approach to CSR could increase transparency, promote trust between the public and the industry, and enhance long-term sustainability. Unfortunately, much CSR activity, particularly the proliferation of 'greenwashing', and the professed motivations behind CSR actions, has increased consumer scepticism and inhibited consumer engagement with genuine CSR actions. Both the nature of the activities undertaken under the auspices of CSR and their motivations, and the manner of their communication are central to overcoming scepticism. We propose that hospitality management investigate in significant detail the communication strategies surrounding CSR in the industry, and how these can be improved to cut through such scepticism. Strategies might include exploring the use of humour in communicating CSR activities, or greater transparency in acknowledging financial benefits.

In terms of reporting, it is by looking across disciplines that we find value in another form of social responsibility research, being that of charities producing Social Return on Investment (SROI) reports. In their study of the CSR reporting of top hotel companies, Holcomb et al. (2007) found that although 80 percent of hotels reported CSR activities, only Hilton did so comprehensively, producing both internal and external CSR audits. Beyond academia, and from the opposite end of the CSR spectrum, charities are under increasing pressure to produce comprehensive SROI reports for investors (Leat, 2006; Nicholls et al., 2009). These reports offer a simple, often numerical understanding of what their money has done for society, via the charity they have funded (Nicholls et al., 2009), e.g. approximate social effect per $£$ invested measured in vaccinations administered or textbooks issued. Although this financial emphasis again carries the risk that more efficient charitable activities are seen as literally more worthy, puts considerable strains on charity resources, and may lead to charities resorting to organisational legitimacy management (think 'organisation-washing') (Neu et al., 1998), this practice certainly shows that it is possible and helpful to analyse and 
publish the long-term social impact of such investments. Although reporting carries its own challenges, CSR research in hospitality might advance by considering the SROI of industry activities, thereby assessing and communicating the long-term social impacts of CSR in a meaningful way.

The suggestion is not that businesses neglect their bottom line, or that the competitive advantage to the business of good CSR be entirely ruled out as an area of study. Nevertheless, CSR should not be seen as a substitute for good business practice, as this may easily function (or at least be perceived) as a diversionary tactic. Rather, CSR activities should be incorporated into already responsible business practices, reflecting upon the wider community an internal attention to the needs of employees, whose living wage should not be considered an act of charity. It is hoped that the interdisciplinary perspective afforded by this literature review will inform future research into CSR activities, prompting investigations into social impacts, whilst ensuring critical awareness of socio-political contexts.

\section{Limitations and further research}

This paper is not without its limitations. First, we opted not to underpin our analysis with meta-analytical techniques, however, extensive systematic reviews of top ranking general and hospitality management literature were conducted, providing strong justification for our conclusions. As a stimulus to refocusing CSR research in hospitality management, we felt this approach most appropriate, and accessible to a wide audience. Second, inconsistencies defining CSR in both general management (Carroll, 1979; Rangan et al., 2015) and hospitality management literature (de Grosbois, 2012; Whitfield et al., 2014) constrained our ability for meta-analysis. It is critical for the development of CSR that research builds incrementally upon prior findings; we minimised this problem by consulting a wide literature base and identifying the most widely applied CSR definitions.

Although we offer a working definition, thereby attending to a significant gap in the literature, there remains considerable scope for further research to explore CSR as an ethical underpinning of the hospitality industry. Researchers might wish to investigate the way in which specific ethical theories (e.g. utilitarian, virtue, existentialist) may be employed to effect positive social and environmental change. Further studies may also look at the extent to which CSR is imbued within organisations as an end-in-itself rather than a means to maximising profit, potentially examining the role of the aforementioned education and training programmes in CSR initiatives. The lack of longitudinal studies, which may be symptomatic of the focus on short-term financial gains, should be remedied in future research.

CSR research remains skewed in favour of Anglo-American (and latterly Asian) contexts, with only tacit consideration of the concept in the Islamic world (Williams and Zinkin, 2010). We call for a widening of investigation of CSR issues to be conducted in Islamic hospitality management contexts, e.g. Qatar's hosting of the 2022 World Cup, and the role of the hospitality industry in both responding to the 2015 Hajj disaster, and ensuring it is not 
repeated. Indeed, investigating the utility of hospitality industry resources and skills in preparing for and providing disaster relief offers a further avenue for research. Of course, such studies should not uncritically adopt concepts from research in Anglo-American, and the potential for the ethical approaches to CSR presented by a global variety of cultural heritages and philosophical traditions should be explored. 


\section{Works Cited}

Acquier, A., Gond, J.P. and Pasquero, J. (2011), “Rediscovering Howard R. Bowen's Legacy: The Unachieved Agenda and Continuing Relevance of Social Responsibilities of the Businessman", Business \& Society, Vol. 50 No. 4, pp. 607646.

Aguinis, H. and Glavas, A. (2012), "What we know and don't know about corporate social responsibility a review and research agenda", Journal of management, Vol. 38 No. 4, pp. 932-968.

Alexander, M., Beveridge, E., C. MacLaren, A. and D. O'Gorman, K. (2014), ““'Responsible drinkers create all the atmosphere of a mortuary"' Policy implementation of responsible drinking in Scotland", International Journal of Contemporary Hospitality Management, Vol. 26 No. 1, pp. 18-34.

al-Tabar1- , ([838]/1989), "تاريخالرسولو الدلوك", State University of New York Press, Albany, NY.

Avraham, E. (2015), "Destination image repair during crisis: "Attracting tourism during the Arab Spring uprisings", Tourism Management, Vol. 47, pp. 224-232.

Benavides-Velasco, C. A., Quintana-García, C. and Marchante-Lara, M. (2014), "Total quality management, corporate social responsibility and performance in the hotel industry", International Journal of Hospitality Management, Vol. 41, pp. 77-87.

Blowfield, M. (2005), "Corporate social responsibility: The failing discipline and why it matters for international relations", International Relations, Vol. 19 No. 2, pp. 173 191.

Bohdanowicz, P., Zientara, P., \& Novotna, E. (2011). "International hotel chains and environmental protection: an analysis of Hilton's we care! Programme", (Europe, 2006-2008). Journal of Sustainable Tourism, Vol. 19 No. 7, pp. 797-816.

Bowen, H. R. (1953), Social responsibilities of the businessman, Harper \& Row, New York.

Brammer, S., Jackson, G. and Matten, D. (2012), "Corporate social responsibility and institutional theory: New perspectives on private governance”, Socio-Economic Review, Vol. 10 No. 1, pp. 3-28.

Brown, T. J. and Dacin, P. A. (1997), "The company and the product: Corporate associations and consumer product responses", The Journal of Marketing, Vol. 61 No. 1, pp. 6884.

Bryce, D., O'Gorman, K. D., \& Baxter, I. W. (2013). "Commerce, empire and faith in Safavid Iran: the caravanserai of Isfahan", International Journal of Contemporary Hospitality Management, Vol. 25 No. 2, pp. 204-226. 
Butler, R., Curran, R. and O'Gorman, K. D. (2013), "Pro-Poor Tourism in a First World Urban Setting: Case Study of Glasgow Govan”, International Journal of Tourism Research, Vol. 15 No. 5, pp. 443-457.

Carroll, A. B. (1979), "A three-dimensional conceptual model of corporate performance”, Academy of management review, Vol. 4 No. 4, pp. 497-505.

Carroll, A. B. (1991). "The pyramid of corporate social responsibility: Toward the moral management of organizational stakeholders", Business horizons, Vol. 34 No. 4, pp. $39-48$.

Carroll, A. B. (1999), "Corporate Social Responsibility: Evolution of a Definitional Construct”, Business \& Society, Vol. 38 No. 3, pp. 268-295.

Carroll, A. B. and Shabana, K. M. (2010), "The business case for corporate social responsibility: a review of concepts, research and practice", International Journal of Management Reviews, Vol. 12 No. 1, pp. 85-105.

Carter, C. R. and Jennings, M. M. (2004), "The role of purchasing in corporate social responsibility: A structural equation analysis", Journal of Business Logistics, Vol. 25 No. 1, pp. 145-186.

Chan, E. S. W., Hon, A. H. Y., Chan, W. and Okumus, F. (2014), "What drives employees' intentions to implement green practices in hotels? The role of knowledge, awareness, concern and ecological behaviour", International Journal of Hospitality Management, Vol. 40, pp. 20-28.

Coles, T., Fenclova, E. and Dinan, C. (2013), "Tourism and corporate social responsibility: A critical review and research agenda", Tourism Management Perspectives, Vol. 6, pp. 122-141.

Dahlsrud, A. (2008), "How corporate social responsibility is defined: an analysis of 37 definitions", Corporate social responsibility and environmental management, Vol. 15 No. 1, pp. 1-13.

Dawkins, C. and Ngunjiri, F. W. (2008), “Corporate Social Responsibility Reporting in South Africa A Descriptive and Comparative Analysis", Journal of Business Communication, Vol. 45 No.3, pp. 286-307.

de Grosbois, D. (2012), “Corporate social responsibility reporting by the global hotel industry: Commitment, initiatives and performance", International Journal of Hospitality Management, Vol. 31 No. 3, pp. 896-905.

Denizci G, B. and Mohammed, I. (2015), "Revenue management research in hospitality and tourism: A critical review of current literature and suggestions for future research", International Journal of Contemporary Hospitality Management, Vol. 27 No. 4, pp. 526-560. 
Denyer, D. and Tranfield, D. (2009), "Producing a systematic review" in Buchanan, D. A. and Bryman, A., eds., The SAGE Handbook of Organizational Research Methods, London: SAGE Publications, pp. 671-689.

Devinney, T. M. (2009), "Is the socially responsible corporation a myth? The good, the bad, and the ugly of corporate social responsibility", The Academy of Management Perspectives, Vol. 23 No. 2, pp. 44-56.

Dibb, S., Simkin, L., Pride, W. M. and Ferrell, O. (2005), Marketing: Concepts and strategies, Houghton Mifflin.

DiPietro, R. B., Cao, Y. and Partlow, C. (2013), "Green practices in upscale foodservice operations", International Journal of Contemporary Hospitality Management, Vol. 25 No. 5, pp. 779-796.

Dodds, R. and Kuehnel, J. (2010), "CSR among Canadian mass tour operators: good awareness but little action”, International Journal of Contemporary Hospitality Management, Vol. 22 No. 2, pp. 221-244.

Donaldson, T. and Preston, L. E. (1995), "The stakeholder theory of the corporation: Concepts, evidence, and implications", Academy of management review, Vol. 20 No. 1 , pp. 65-91.

Fleming, P., \& Jones, M. T. (2012). The End of Corporate Social Responsibility: Crisis and Critique: SAGE Publications.

Friedman, M. (1970): The Social Responsibility of Business is to Increase its Profits., New York Times Magazine, Sept. 13, pp. $122-126$.

Fu, H., Ye, B. H. and Law, R. (2014), "You do well and I do well? The behavioral consequences of corporate social responsibility", International Journal of Hospitality Management, Vol. 40, pp. 62-70.

Galbreath, J. (2010), "Drivers of Corporate Social Responsibility: the Role of Formal Strategic Planning and Firm Culture", British Journal of Management, Vol. 21 No. 2 , pp. 511-525.

Garay, L. and Font, X. (2012), "Doing good to do well? Corporate social responsibility reasons, practices and impacts in small and medium accommodation enterprises", International Journal of Hospitality Management, Vol. 31 No. 2, pp. 329-337.

Gjølberg, M. (2009), “The origin of corporate social responsibility: global forces or national legacies?”, Socio-Economic Review, Vol. 7 No. 4, pp. 605-637.

Godfrey, P. C. (2005), "The relationship between corporate philanthropy and shareholder wealth: A risk management perspective", Academy of management review, Vol. 30 No. 4, pp. 777-798. 
Godfrey, P. C., Merrill, C. B. and Hansen, J. M. (2009), “The relationship between corporate social responsibility and shareholder value: An empirical test of the risk management hypothesis", Strategic management journal, Vol. 30 No. 4, pp. 425-445.

Hanlon, G. (2008), Rethinking corporate social responsibility and the role of the firm-on the denial of politics, in Crane, A., McWilliams, A., Matten, D., Moon, J., Siegel, D. (Ed.), The Oxford handbook of corporate social responsibility, Oxford University Press, Oxford, pp. $156-172$.

Harvey, D. (2005), A brief history of neoliberalism, Oxford University Press, Oxford.

Henderson, D. (2005), "The role of business in the world of today", Journal of Corporate Citizenship, Vol. 17 No. 3, pp. 30-32.

Henderson, J. C. (2007), "Corporate social responsibility and tourism: Hotel companies in Phuket, Thailand, after the Indian Ocean tsunami”, International Journal of Hospitality Management, Vol. 26 No. 1, pp. 228-239.

Holcomb, J. L., Upchurch, R. S. and Okumus, F. (2007), “Corporate social responsibility: what are top hotel companies reporting?", International Journal of Contemporary Hospitality Management, Vol. 19 No. 6, pp. 461-475.

Holden, A. (2009), "The environment-tourism nexus: Influence of market ethics", Annals of Tourism Research, Vol. 36 No. 3, pp. 373-389.

Inoue, Y. and Lee, S. (2011), "Effects of different dimensions of corporate social responsibility on corporate financial performance in tourism-related industries", Tourism Management, Vol. 32 No. 4, pp. 790-804.

Jolliffe, L. and Farnsworth, R. (2003), "Seasonality in tourism employment: human resource challenges", International Journal of Contemporary Hospitality Management, Vol. 15 No. 6, pp. 312-316.

Jones, C. (2003). “As if Business Ethics were Possible, 'within Such Limits'....”, Organization, Vol. 10 No. 2, pp. 223-248.

Jones, P., Comfort, D. and Hillier, D. (2006a), "Reporting and reflecting on corporate social responsibility in the hospitality industry: A case study of pub operators in the UK", International Journal of Contemporary Hospitality Management, Vol. 18 No. 4, pp. 329-340.

Jones, P., Comfort, D. and Hillier, D. (2006b), "Corporate social responsibility and the UK construction industry”, Journal of Corporate Real Estate, Vol. 8 No. 3, pp. 134-150.

Jones, P., Hillier, D., \& Comfort, D. (2016). "Sustainability in the hospitality industry: some personal reflections on corporate challenges and research agendas", International Journal of Contemporary Hospitality Management, Vol. 28 No. 1, pp. 36-67. 
Kang, K. H., Lee, S. and Huh, C. (2010), "Impacts of positive and negative corporate social responsibility activities on company performance in the hospitality industry", International Journal of Hospitality Management, Vol. 29 No. 1, pp. 72-82.

Kemper, J., Schilke, O., Reimann, M., Wang, X. and Brettel, M. (2013), “Competitionmotivated corporate social responsibility", Journal of Business Research, Vol. 66 No. 10, pp. 1954-1963.

Kim, E. E. K., Kang, J. and Mattila, A. S. (2012), "The impact of prevention versus promotion hope on CSR activities", International Journal of Hospitality Management, Vol. 31 No. 1, pp. 43-51.

Kim, M. and Kim, Y. (2014), "Corporate social responsibility and shareholder value of restaurant firms", International Journal of Hospitality Management, Vol. 40, pp. 120129.

Kim, S., Yoon, J. and Shin, J. (2015), "Sustainable business-and-industry foodservice: consumers' perception and willingness to pay a premium in South Korea", International Journal of Contemporary Hospitality Management, Vol. 27 No. 4, pp. 648-669.

Kinderman, D. (2012), “'Free us up so we can be responsible!' The co-evolution of Corporate Social Responsibility and neo-liberalism in the UK, 1977-2010", SocioEconomic Review, Vol. 10 No. 1, pp. 29-57.

Kundur, S.K. (2012) "Development of Tourism in Maldives", International Journal of Scientific and Research Publications, Vol. 2 No. 4, pp. 1-5.

Laczniak, G, R. and Murphy, P. E. (2012), "Stakeholder Theory and Marketing: Moving from a Firm-Centric to a Societal Perspective", Journal of Public Policy \& Marketing, Vol. 31 No. 2, pp. 284-292.

Lantos, G. P. (2001). “The boundaries of strategic corporate social responsibility". Journal of consumer marketing, Vol. 18 No. 7, pp. 595-632.

Lantos, G. P. (2002). “The ethicality of altruistic corporate social responsibility”. Journal of consumer marketing, Vol. 19 No. 3, pp. 205-232.

Larner, W. (2000), "Neo-liberalism: Policy, ideology, governmentality." Studies in political economy Vol. 63 No. 1, pp. 5-25.

Leat, D. (2006), “Grantmaking Foundations and Performance Measurement: Playing Pool?”, Public Policy and Administration, Vol. 21 No. 3, pp. 25-37.

Lee, C. K., Song, H. J., Lee, H. M., Lee, S. and Bernhard, B. J. (2013), “The impact of CSR on casino employees' organizational trust, job satisfaction, and customer orientation: An empirical examination of responsible gambling strategies", International Journal of Hospitality Management, Vol. 33, pp. 406-415. 
Lee, M. D. P. (2008), “A review of the theories of corporate social responsibility: Its evolutionary path and the road ahead", International Journal of Management Reviews, Vol. 10 No. 1, pp. 53-73.

Lee, S. and Heo, C. Y. (2009), "Corporate social responsibility and customer satisfaction among US publicly traded hotels and restaurants", International Journal of Hospitality Management, Vol. 28 No. 4, pp. 635-637.

Lee, S. and Park, S.Y. (2009), "Do socially responsible activities help hotels and casinos achieve their financial goals?", International Journal of Hospitality Management, Vol. 28 No. 1, pp. 105-112.

Lee, S., Singal, M. and Kang, K. H. (2013), “The corporate social responsibility-financial performance link in the U.S. restaurant industry: Do economic conditions matter?", International Journal of Hospitality Management, Vol. 32, pp. 2-10.

Lee, Y. K., Lee, K. H. and Li, D. X. (2012), "The impact of CSR on relationship quality and relationship outcomes: A perspective of service employees", International Journal of Hospitality Management, Vol. 31 No. 3, pp. 745-756.

Li, L. (2008), "A review of entrepreneurship research published in the hospitality and tourism management journals”, Tourism Management, Vol. 29 No. 5, pp. 1013-1022.

Lindgreen, A. and Swaen, V. (2010), "Corporate social responsibility", International Journal of Management Reviews, Vol. 12 No. 1, pp. 1-7.

Liu, M. T., Wong, I. A., Rongwei, C. and Tseng, T.H. (2014), "Do perceived CSR initiatives enhance customer preference and loyalty in casinos?", International Journal of Contemporary Hospitality Management, Vol. 26 No. 7, pp. 1024-1045.

Luo, X. and Bhattacharya, C. B. (2006), "Corporate social responsibility, customer satisfaction, and market value", Journal of Marketing, Vol. 70 No. 4, pp. 1-18.

Martínez, P. and Rodríguez del Bosque, I. (2013), "CSR and customer loyalty: The roles of trust, customer identification with the company and satisfaction", International Journal of Hospitality Management, Vol. 35, pp. 89-99.

McWilliams, A. and Siegel, D. (2000), "Corporate social responsibility and financial performance: correlation or misspecification?", Strategic management journal, Vol. 21 No. 5, pp. 603-609.

Mintzberg, H. (1983). "The case for corporate social responsibility". Journal of Business Strategy, Vol. 4 No. 2, pp. 3-15.

Moore, G. (2003). "Hives and horseshoes, Mintzberg or MacIntyre: what future for corporate social responsibility?” Business Ethics: A European Review, Vol. 12 No. 1, pp. 41-53. 
Morrison, A., \& O'Gorman, K. (2008). "Hospitality studies and hospitality management: A symbiotic relationship", International Journal of Hospitality Management, Vol. 27 No. 2, pp. 214-221.

Murphy, P. E. and Schlegelmilch, B. B. (2013), "Corporate social responsibility and corporate social irresponsibility: Introduction to a special topic section", Journal of Business Research, Vol. 66 No. 10, pp. 1807-1813.

Neu, D., Warsame, H. and Pedwell, K. (1998), "Managing Public Impressions: Environmental Disclosures in Annual Reportsa", Accounting, Organizations and Society, Vol. 23 No. 3, pp. 265-282.

Nicholls, J., Cupitt, S. and Durie, S. (2009), A guide to Social Return on Investment, Cabinet Office, Office of the Third Sector.

Nicolau, J. L. (2008), “Corporate Social Responsibility: Worth-Creating activities”, Annals of Tourism Research, Vol. 35 No. 4, pp. 990-1006.

Nikolaou, I. E., Evangelinos, K. I. and Allan, S. (2013), “A reverse logistics social responsibility evaluation framework based on the triple bottom line approach", Journal of Cleaner Production, Vol. 56, pp. 173-184.

Noland, J. and Phillips, R. (2010), "Stakeholder engagement, discourse ethics and strategic management”, International Journal of Management Reviews, Vol. 12 No, 1, pp. 3949.

Nyahunzvi, D. K. (2013), “CSR reporting among Zimbabwe's hotel groups: a content analysis", International Journal of Contemporary Hospitality Management, Vol. 25 No. 4, pp. 595-613.

O'Gorman, K.D. (2009), “Origins of the commercial hospitality industry: from the fanciful to factual”, International Journal of Contemporary Hospitality Management, Vol. 21 No. 7, pp. 777-90

O'Gorman, K.D. (2010), The Origins of Hospitality and Tourism, Goodfellow Publishers, Oxford.

Okumus, F., Altinay, M. and Arasli, H. (2005), "The impact of Turkey's economic crisis of February 2001 on the tourism industry in Northern Cyprus", Tourism Management, Vol. 26 No. 1, pp. 95-104.

Orlitzky, M., Siegel, D. S. and Waldman, D. A. (2011), "Strategic corporate social responsibility and environmental sustainability", Business \& Society, Vol. 50 No. 1, pp. 6-27.

Owen, D. (2005), “CSR after Enron: A Role for the academic accounting profession?", European Accounting Review, Vol. 14 No. 2, pp. 395-404. 
Parguel, B., Benoît-Moreau, F. and Larceneux, F. (2011), "How Sustainability Ratings Might Deter 'Greenwashing”: A Closer Look at Ethical Corporate Communication', Journal of Business Ethics, Vol. 102 No. 1, pp. 15-28.

Park, S.Y. and Levy, S. E. (2014), "Corporate social responsibility: perspectives of hotel frontline employees", International Journal of Contemporary Hospitality Management, Vol. 26 No. 3, pp. 332-348.

Podnar, K. and Golob, U. (2007), "CSR expectations: the focus of corporate marketing", Corporate Communications An International Journal, Vol. 12 No. 4, pp. 326-340.

Pope, S. and Wæraas, A. (2015), "CSR-Washing is Rare: A Conceptual Framework, Literature Review, and Critique”, Journal of Business Ethics, Vol. 137 No. 1, pp. 173-193.

Rangan, K., Chase, L. and Karim, S. (2015), "The truth about CSR", Harvard Business Review, Vol. 93 No. 1/2, pp. 40-49.

Rodríguez, F. J. G. and Cruz, Y. D. M. A. (2007), "Relation between social-environmental responsibility and performance in hotel firms", International Journal of Hospitality Management, Vol. 26 No. 4, pp. 824-839.

Sadler, D. and Lloyd, S. (2009), "Neo-liberalising corporate social responsibility: A political economy of corporate citizenship", Geoforum, Vol. 40 No. 4, pp. 613-622.

Salzmann, O., Ionescu-Somers, A. and Steger, U. (2005), “The business case for corporate sustainability: literature review and research options", European Management Journal, Vol. 23 No. 1, pp. 27-36.

Sandoval, M. (2015), "From CSR to RSC: A Contribution to the Critique of the Political Economy of Corporate Social Responsibility", Review of Radical Political Economics, Vol. 47 No. 4, pp. 608-624.

Sen, S. and Bhattacharya, C. B. (2001), "Does doing good always lead to doing better? Consumer reactions to corporate social responsibility", Journal of marketing Research, Vol. 38 No. 2, pp. 225-243.

Scherer, A. G., \& Palazzo, G. (2011). The new political role of business in a globalized world: A review of a new perspective on CSR and its implications for the firm, governance, and democracy. Journal of Management Studies, Vol. 48 No. 4, pp. 899931.

Shamir, R. (2004), "The de-radicalization of corporate social responsibility", Critical Sociology, Vol. 30 No. 3, pp. 669-689.

Simon, F. L. (1995), "Global corporate philanthropy: a strategic framework", International Marketing Review, Vol. 12 No. 4, pp. 20-37.

Singer, P. (2005). "Ethics and intuitions", The Journal of Ethics, Vol. 9 No. 3-4, pp. 331-352. 
Siu, N. Y.M., Zhang, T. J.F. and Kwan, H.Y. (2014), "Effect of corporate social responsibility, customer attribution and prior expectation on post-recovery satisfaction”, International Journal of Hospitality Management, Vol. 43, pp. 87-97.

Skarmeas, D., Leonidou, C. N. and Saridakis, C. (2014), "Examining the role of CSR skepticism using fuzzy-set qualitative comparative analysis", Journal of Business Research, Vol. 67 No. 9, pp. 1796-1805.

Song, H., Lin, S., Witt, S. F. and Zhang, X. (2011), "Impact of financial/economic crisis on demand for hotel rooms in Hong Kong”, Tourism Management, Vol. 32 No. 1, pp. 172-186.

Spence, C. and Thomson, I. (2009), "Resonance tropes in corporate philanthropy discourse", Business Ethics: A European Review, Vol. 18 No, 4, pp. 372-388.

Tsai, H., Hsu, J.L., Chen, C.H., Lin, W.R. and Chen, S.P. (2010), “An integrated approach for selecting corporate social responsibility programs and costs evaluation in the international tourist hotel", International Journal of Hospitality Management, Vol. 29 No. 3, pp. 385-396.

Tsai, H., Tsang, N. K. and Cheng, S. K. (2012), "Hotel employees' perceptions on corporate social responsibility: The case of Hong Kong", International Journal of Hospitality Management, Vol. 31 No. 4, pp. 1143-1154.

Vaaland, T. I., Heide, M. and Grønhaug, K. (2008), “Corporate social responsibility: investigating theory and research in the marketing context", European Journal of Marketing, Vol. 42 No. 9/10, pp. 927-953.

Van Marrewijk, M. (2003), "Concepts and Definitions of CSR and Corporate Sustainability: Between Agency and Communion", Journal of Business Ethics, Vol. 44 No. 2/3, pp. 95-105.

Van Beurden, P. \& Gössling, T. (2008). "The worth of values-a literature review on the relation between corporate social and financial performance." Journal of Business Ethics, Vol. 82, pp. 407-424.

Vlachos, P., Tsamakos, A., Vrechopoulos, A. and Avramidis, P. (2009), "Corporate social responsibility: attributions, loyalty, and the mediating role of trust", Journal of the Academy of Marketing Science, Vol. 37 No. 2, pp. 170-180.

Wang, C.J. (2014), “Do ethical and sustainable practices matter?”, International Journal of Contemporary Hospitality Management, Vol. 26 No. 6, pp. 930-947.

Wearing, S. and McGehee, N. G. (2013), "Volunteer tourism: A review", Tourism Management, Vol. 38, pp. 120-130. 
Wells, V. K., Manika, D., Gregory-Smith, D., Taheri, B. and McCowlen, C. (2015), "Heritage tourism, CSR and the role of employee environmental behaviour", Tourism Management, Vol. 48, pp. 399-413.

Whitfield, J., Dioko, L. A. and Webber, D. E. (2014), "Scoring environmental credentials: a review of UK conference and meetings venues using the GREENER VENUE framework", Journal of Sustainable Tourism, Vol. 22 No. 2, pp. 299-318.

Wildes, V. J. (2008), "How can organizational leaders really lead and serve at the same time?", International Journal of Contemporary Hospitality Management, Vol. 20 No. 1, pp. 67-78.

Williams, G. and Zinkin, J. (2010), "Islam and CSR: A study of the compatibility between the tenets of Islam and the UN Global Compact", Journal of Business Ethics, Vol. 91 No. 4, pp. 519-533.

Wood, D. J. (1991), “Corporate social performance revisited”, Academy of management review, Vol. 16 No. 4, pp. 691-718.

World Business Council for Sustainable Development (1999), Corporate Social Responsibility: Meeting changing expectations Conches-Geneva, Switzerland: World Business Council for Economic Development.

$\mathrm{Xu}, \mathrm{Y}$. (2014), "Understanding CSR from the perspective of Chinese diners: the case of McDonald's", International Journal of Contemporary Hospitality Management, Vol. 26 No. 6, pp. 1002-1020.

Zeng, B. and Ryan, C. (2012), "Assisting the poor in China through tourism development: A review of research", Tourism Management, Vol. 33 No. 2, pp. 239-248. 


\section{Figure 1}

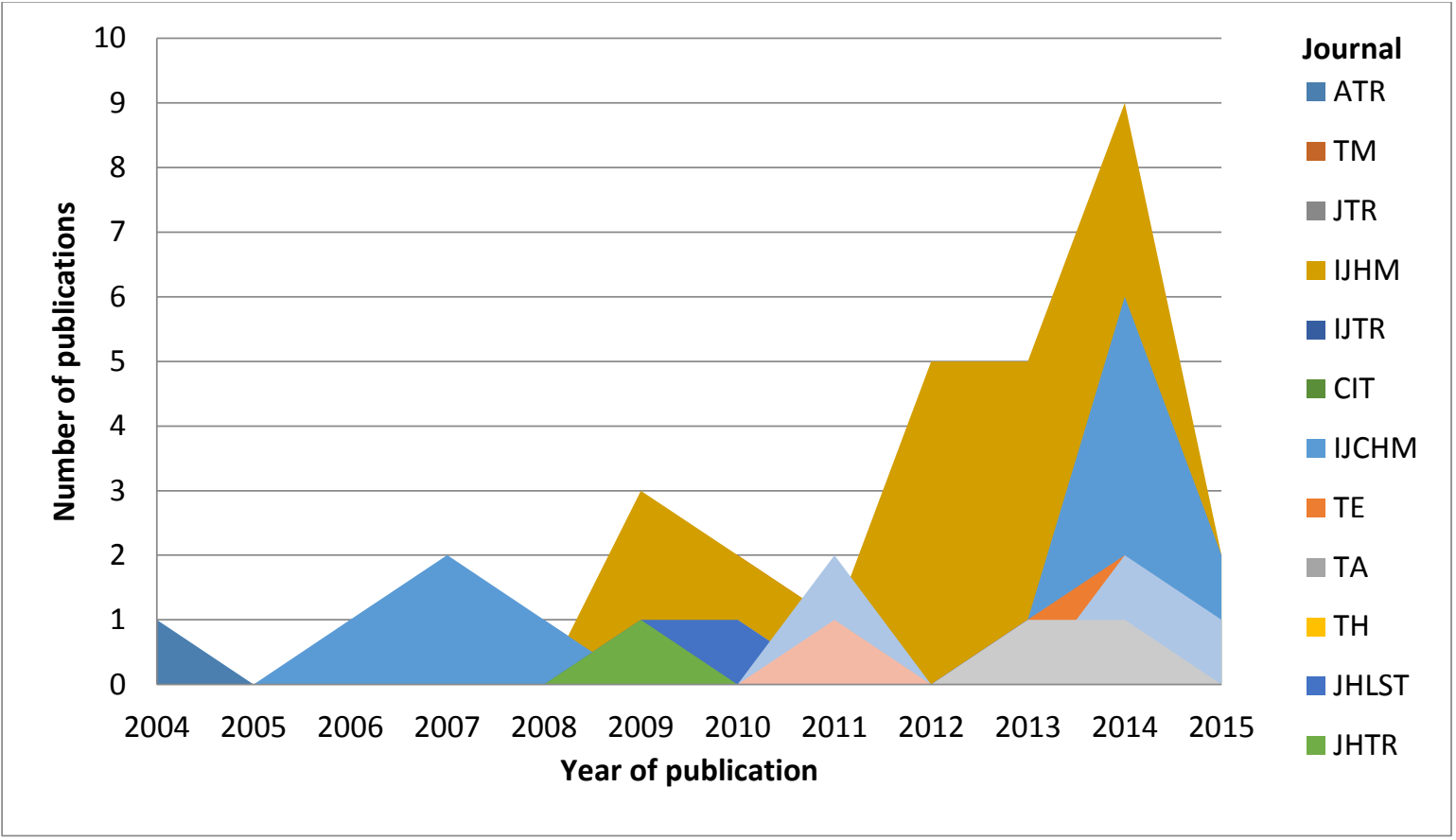

Figure 1: Number of articles on CSR in hospitality by journal and year of publication.

Abbreviations: ATR: Annals of Tourism Research; TM: Tourism Management; JTR: Journal of Travel Research; IJHM: International Journal of Hospitality Management; IJTR: International Journal of Tourism Research; CIT: Current Issues in Tourism; IJCHM: International Journal of Contemporary Hospitality Management; TE: Tourism Economics; TA: Tourism Analysis; TH: Tourism and Hospitality: Planning and Development; JHLST: Journal of Hospitality, Leisure, Sport and Tourism Education; JHTR: Journal of Hospitality and Tourism Research; JST: Journal of Sustainable Tourism; JHTM: Journal of Hospitality and Tourism Management; JTTM: Journal of Travel and Tourism Marketing. 
Table 1

\begin{tabular}{|c|c|c|c|c|c|c|c|}
\hline JOURNAL & Internal & External & Holistic & Processual & Reporting & Conceptual & TOTAL \\
\hline ATR & & 2 & & & & & 2 \\
\hline TM & 2 & 1 & 1 & 4 & 2 & & 10 \\
\hline JTR & & 1 & 1 & 1 & & 1 & 4 \\
\hline IJHM & 18 & 2 & & 6 & 2 & & 28 \\
\hline IJTR & 1 & & & & & 1 & 2 \\
\hline CIT & 2 & 1 & & & & 1 & 4 \\
\hline IJCHM & 5 & & 1 & 5 & 2 & 1 & 14 \\
\hline TE & 2 & & & & & 1 & 3 \\
\hline TA & & & & 1 & & & 1 \\
\hline TH & & & & & & 1 & 1 \\
\hline JHLST & 2 & & 1 & & & & 3 \\
\hline JHTR & & & 1 & & & & 1 \\
\hline JST & 1 & 1 & & 1 & 2 & & 5 \\
\hline JHTM & 1 & & & & & & 1 \\
\hline JTTM & 1 & & 1 & & & & 2 \\
\hline TOTAL & 35 & 8 & 6 & 18 & 8 & 6 & 81 \\
\hline
\end{tabular}

Table 1: Contributions to CSR research in hospitality by journal and article type. 
